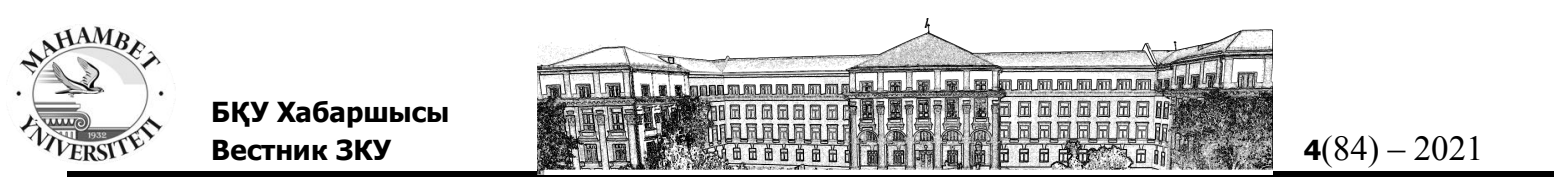

UDC 81 '243

IRSTI 16.41 .21

DOI $10.37238 / 1680-0761.2021 .84(4) .40$

\author{
Abiltayeva Aida* \\ M. Utemisov West Kazakhstan University, Uralsk, Kazakhstan \\ *Correspondence: abiltaevaaida@mail.ru
}

\title{
E-mail: abiltaevaaida@mail.ru \\ GROUP DISCUSSION IN DEVELOPMENT OF STUDENTS' LISTENING SKILLS IN A FOREIGN LANGUAGE
}

\begin{abstract}
Annotation. The researchers wanted to examine what problems students faced while learning to listen in a group conversation and which aspect of listening worked better than the other. A questionnaire, a pre-test, and a post-test were used to collect information. Students' answers for macro and micro-skills were interpreted, averaged, and compared using pre-and posttest data. Students experienced five major concerns, according to the findings: talking about something else while talking about something else, not contributing, dominating buddy, groupmate, and willingness to lead a debate. When it comes to listening abilities, the children performed better in macro-skills than micro-skills. Finally, due of the existence of schemata in the top-down process, the imperfect condition of argument might cause issues in discussion, and macro-skills can perform better.
\end{abstract}

Keywords. Group discussion; understanding; listening skills; macro and micro - skills; group work; listening; active learning; discussion activities; report.

\section{Introduction}

Receivers must "understand the text as they hear it, keep the information in mind, integrate it with the next thing, and constantly change their understanding of what they hear based on knowledge previous information and incoming information" [1, p. 60]]. The development of listening skills was examined through intensive comprehensive listening [2, p. 34]. "Listening in real life" [3, p. 301] participatory and may require more than "implicit input" [4, p. 16]. Accordingly, this paper takes a unique approach, arguing that listening comprehension can be enhanced through interactions in which students engage in groups to actively discover, share, discuss, and report. If work takes longer and relationships are frequent, we talk about a formal cooperative [5, p. 53]. Teachers can divide students into groups based on their interests, gender, or even academic achievement. Students should work together to achieve specific goals while the teacher monitors their progress [6, p. 33]. Clearly, this level of performance requires coaches to be more prepared and effortless. Teachers need to set clear goals that are compatible with the academic and professional abilities of their students. When teachers want to build long - term projects or relationships with their students, they use the core group. It is possible to have a hard heart for a full academic year and act on or replace informal and formal forms of cooperation [7, p. 54]. To summarize, the implemented intervention (group discussion activities) constitutes formal group labor, with goals, a set time limit, and a required final report, as indicated in Figure 1. One of the cooperative learning kinds that strongly portrays active learning is the formal group. 

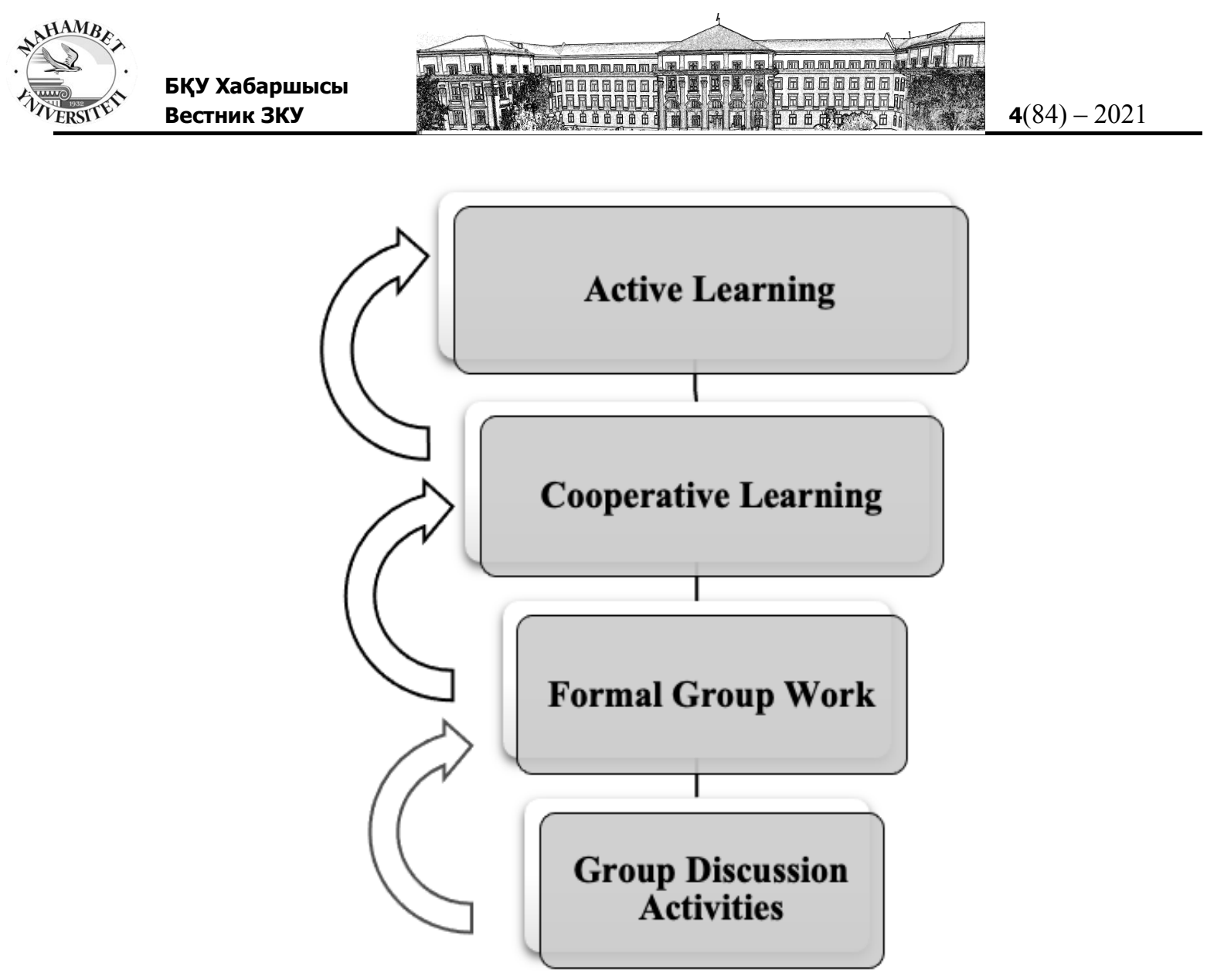

Figure 1 - Intervention: Group discussion activities

English is one of the most widely used languages for worldwide communication. However, English is taught in schools in Kazakhstan, although it is not the primary mode of communication. Listening for mediation is a kind of communication that can be used in addition to speaking. The ability to listen is the first step in learning a language. If a person never hears how to pronounce these words, he or she will be unable to identify the pronunciation. Hearing is about recalling noises from a sound source, according to Hornby, who was mentioned in Putra. The listening process, according to Gebhard [8, p. 144], has two stages: bottom-up and top-down. The process of interpreting meaning is known as the bottom-up process. The listener absorbs information through sounds, words, and grammar in this process. To comprehend meaning, the top-down approach uses schemata. In listening exercises, there are two abilities that are inextricably linked. They have macro and micro listening skills. Macro skills are excellent listening abilities that are simple to comprehend. Understanding what the speaker said is a macro-skill. Micro-skill refers to a specific aspect of listening. It's more difficult to comprehend since they must comprehend not just what has been stated, but also word choices, deeper meanings, purposes, and attitudes in order to relay the message. Brown has improved Richard's auditory taxonomy by providing a concise list of macro and micro-skills for conversational listening. The macro-skills are concerned with the level of discourse structure, whereas the micro-skills are concerned with the level of sentence organization [9, p. 44].

In addition to listening, this study emphasized group discussion. A group discussion is a gathering of people who meet informally to discuss a specific topic. Members or participants use listening and speaking skills during conversations. By convention, group discussions are a central educational concept for teachers who strive for moderate student engagement [10, p. 56].

The debate may be unexpected for whatever reason. It definitely needs a teacher to function as an instructor through dialogues that give a broad range of possibilities to investigate and learn new things [11, p. 34]. Teachers can help students overcome issues that commonly arise in group 


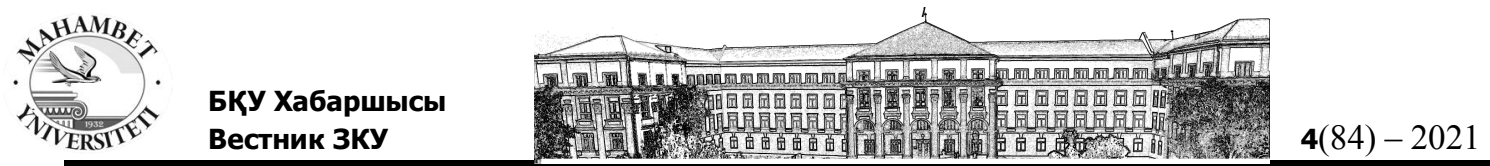

talks, such as shyness and dominance. According to the theory of immersion, the dominating student might generate issues for the other students. Inappropriate materials may wreak havoc as well. The learner will not be interested in [12, p. 11] if the content chosen is improper for him. Based on the preceding description, the researcher looked at the issues that students from School N. 3 experienced when studying listening in a group discussion, and which component of listening performed better than the other.

\section{Methods}

This study used descriptive qualitative methods. Descriptive research is a type of study that includes observing and describing the behavior of the participants without interfering in any manner. Because they struggled in the listening phase, the research was done in class IX F. The researchers made various plans before implementing the study program. They were: deciding on a study topic, gathering resources, and putting together a lesson plan. The researchers ran a trial test in the IX $\mathrm{C}$ class on the first day of the study to determine the exam's quality. There are 50 questions and four options in the test ( $\mathrm{a}, \mathrm{b}, \mathrm{c}$, and $\mathrm{d})$. To answer all of the questions, you will have 80 minutes. The researchers used pre-test, post-test, and questionnaire questionnaires to gather data. Pre-testing takes place in class IX F, followed by group discussions. In Class IX F, the post-test was administered. As instructors, the researchers cope with listening by having students participate in group discussions. The final step is to conduct a student questionnaire survey. This is the conclusion of the research. This study's instruments have both content and structural validity. The test question's content validity must cover all of the elements of the test question. At the same time, structural validity refers to a test that examines the relationship between the language's tools and theories. When assessing an element or structure, evaluation tools require structural validity, which includes several signs. The dependability of the test is calculated using the split-half approach. The researcher utilizes the Spearman Brown method to calculate the reliability coefficient between the odd and even numbers while analyzing the test's dependability. The researchers then utilized Spearman Brown's prediction technique to get the entire item coefficient's correlation. After gathering the data, the next step was to analyze it. The data from the questionnaire was gathered and analysed by the researcher. The researcher then tabulated, averaged, compared, and described the findings from both the pre-test and post-test. In the last phase, the triangulation approach was employed to reach a conclusion.

\section{Results and discussions}

The researcher used a preliminary, post-test, and questionnaire survey to gather data. The preliminary exam was required in order to determine the pupils' fundamental understanding in the listening part prior to treatment. The post-test was required to determine how well the pupils could interpret the text by ear following the treatment. The questionnaire was required in order to collect data on students' issues in the study of listening through group discussion.

\section{Students' Responds of the Questionnaire}

Student questions may be categorized into five categories based on the replies to the student survey. The first issue is with the students who were in charge of the group. The second issue was a buddy who refused to help. My groupmates were the third issue. The fourth and last concern about the desire to take the lead in talks is the tendency to talk about something else while talking about something else.

The following table shows the students' respond of questionnaire:

\begin{tabular}{|l|l|l|l|}
\hline No. & Statement & \multicolumn{2}{|l|}{ Respond } \\
\cline { 3 - 4 } & Yes & No \\
\hline 1. & $\begin{array}{l}\text { I feel unhappy to ask to my friends in my group } \\
\text { discussion }\end{array}$ & 6 & 25 \\
\hline 2. & $\begin{array}{l}\text { I feel unhappy to speak to my friends in my group } \\
\text { discussion }\end{array}$ & 8 & 23 \\
\hline
\end{tabular}




\begin{tabular}{|l|l|l|l|}
\hline & \multicolumn{1}{|l}{ 4(84)-2021 } \\
\hline 4. & $\begin{array}{l}\text { I always feel happy to ask to my friend in group } \\
\text { discussion }\end{array}$ & 12 & 19 \\
\hline 5. & $\begin{array}{l}\text { I always feel happy to speak to my friend in group } \\
\text { discussion }\end{array}$ & 8 & 23 \\
\hline 6. & $\begin{array}{l}\text { I don't like if one of my friends doesn't give any } \\
\text { contribution in discussion }\end{array}$ & 24 & 7 \\
\hline 7. & $\begin{array}{l}\text { I feel inconvenient with my friends in group } \\
\text { discussion }\end{array}$ & 19 & 12 \\
\hline 8. & $\begin{array}{l}\text { I don't like doing a task by group discussion } \\
\text { I always want to be a leader in group discussion }\end{array}$ & 2 & 29 \\
\hline 9. & \begin{tabular}{l} 
I don't want to be a leader in group discussion \\
\hline 10.
\end{tabular} & 22 & 9 \\
\hline 11. & $\begin{array}{l}\text { I always being passive member and depend on my } \\
\text { smart friend to finish my work }\end{array}$ & 5 & 26 \\
\hline 12. & $\begin{array}{l}\text { I will not defend my argument if my friends don't like } \\
\text { it }\end{array}$ & 11 & 20 \\
\hline 13. & $\begin{array}{l}\text { I usually talk about another topic to my friend while } \\
\text { discussing }\end{array}$ & 15 & 16 \\
\hline
\end{tabular}

According to the information presented above, students confront five major issues.

Students are debating and speaking about the first question. This might be due to the materials utilized. Inappropriate materials might pose issues for pupils if they are excessively challenging or dull. Students believe that conversing might help them deal with their boredom with the materials. In agreement with Immerwahr, he stated that improper content would bore students.

The trouble of non-contributing contributors is the second. The student's participation to the conversation will be harmed due to the forget about of a buddy. This argument contradicts Zander's thought seeing that instructors urge college students to take phase in group discussions [13, p. 24]. Because she is uncomfortable or hesitant to ask and does no longer talk, her friends will pick out her as a member who only wishes to score and now not work, and she will be counted on different teammates. She or he, on the other hand, might also act in this manner as a result of being omitted through her or his teammates. She or he will subsequently end up a passive and lazy member.

The third difficulty is that of the dominating student. Even if gorgeous students have been below pressure to do the venture quickly, they would reason difficulties for the different individuals if they pretended to be smart, were too greedy, or had been too dictatorial. It is realistic to assume that the student monopolizes or dominates the debate. According to Immerwahr, dominating students may be an difficulty for the the rest of the group.

Fourth, being overlooked and a non-contributing member is one of the reasons why some students find their group-mate bothersome during a debate. In certain cases, the teacher assigns students to groups, so there will be a mix of male and female pupils. It also posed problems for some students since they will feel "clicked" if their group-mate is of the same gender as them, for example, an all-males or all-females group. In agreement with Reineke, who claims that students would occasionally consider group selection based on gender and will feel comfortable communicating with [14, p. 71$]$.

Fifth is apprehensive about taking the lead in a discussion. The leader has a lot of responsibility, and most students don't want to be the group's leader. They believe that becoming the leader will be tough and that they are not capable of doing it. Another motive arises if becoming a leader has a high likelihood of completing the work alone, because members will occasionally 


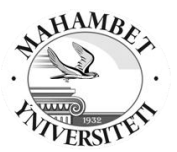

delegate duty to the leader. The key issues mentioned above may have an impact on the listening portion. The purpose of a group discussion is to share information, ideas, and roles with the other members of the group. However, if the group's condition is poor, the listening section will be distracted and will not run optimally. Similarly, the student's inconvenient with the group prevents the student from focusing on the assignment.

\section{Macro and Micro-Skills}

During pre- and post-testing, macro and micro-skill ratings were acquired. The common macro and micro ability score on each test used to be then computed by way of the researcher. The researcher subsequent contrasted the two talents in each exam. Here are the comparative tables:

\begin{tabular}{|l|l|l|}
\hline \multirow{2}{*}{$\begin{array}{l}\text { LISTENING } \\
\text { SKILL }\end{array}$} & \multicolumn{2}{|l|}{ TYPE OF TEST } \\
\cline { 2 - 3 } & PRE-TEST & POST-TEST \\
\hline MICRO-SKILLS & 8.4688 & 10.4839 \\
\hline MACRO-SKILLS & 10.75 & 14.3226 \\
\hline GAIN & 2.2812 & 3.8387 \\
\hline
\end{tabular}

In each exam, there used to be a distinction between macro and micro-skills, as considered in the table. Pre-test outcomes confirmed that macro-skills carried out better than micro-skills, with a reap of 2.2812. The make bigger used to be 3.8387 in the post-test, with macro abilities outperforming micro-skills. According to the information amassed from the pre-test to the post-test, macro-skills performed higher than micro-skills as a listening component. Macroskills refer to a giant share of listening competencies that college students ought to grasp established on the text's discourse level. Brown, who believes macro-skills to be worried with discourse level, agrees. According to Antonjjensen, macro-skills are simple to understand given that human beings simply pay attention to what the speaker says. Micro-skills, on the other hand, refer to specific aspects of listening. According to Antonjjensen, they are difficult to comprehend since the listener must comprehend not only what was said, but also the terminology used, the deeper meaning, and so on. Microskills, according to Brown, are concerned with sentence level. As a result, macro-skills outperformed micro-skills [15, p. 39].

The outcome can also be viewed via the lens of the listening process. According to Gebhard, there are two types of listening processes: top-down and bottom-up listening. The listener concentrates on a substantial portion of the material or has to do with general abilities in the descending process. The listener also incorporates strategies for comprehending the meaning of the information in this process. The striatum refers to the process of recalling information stored in the brain's long-term memory.

Schemata, or what is many times referred to as heritage information, play an important function in appreciation the content and making it less complicated to comprehend. The more schemata in the brain, the higher the content material understanding. When a listener receives information, he or she does now not immediately hold close it; instead, the listener makes use of background know-how to be aware of it, such as the kind of information, who the speaker is, the place the place is, and so on. Even earlier than the records is delivered to the listeners, they spark off their prior appreciation of the situation. The gaining knowledge of of holistic competencies can be facilitated by means of returning to the listening process, which is a top-down process diagram. The top-down approach is centered on the utilization of schemas that listen on processing facts and translating it into a central notion. Meanwhile, from bottom to top, some other listening technique concentrates on processing information that influences grammatical structure, sound, phrases, and 


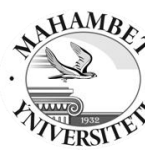

so forth. As a consequence, the outcomes revealed that macro capabilities performed higher than micro skills. Those whose listening method used to be influenced via the existence of planning or previous information.

\section{Conclusions}

The researcher comes to the following conclusion based on the findings of this study:

1. There are five major issues that students confront. One is that pupils have issues with the learning materials, thus they choose to talk about anything else while doing so. The second question is about friends who haven't contributed, the third is about the dominating friend's query, the fourth is about group members, and the final question is about the desire to lead the debate. Students' issues are created by insufficient environment for group discussion.

2. Students have a better comprehension of macro-skills in listening than micro-skills. Macro-skills fared better than micro-skills in both the pre-test and post-test, according to the findings and discussion of this study. Macro abilities might be improved due to their simplicity and the presence of schemata, which impacts the top-down listening process. Based on the conclusions above, the researcher proposes some suggestions:

1. It is preferable for the teacher to awaken students' attention and spark off their schemata before educating listening. It is the teacher's accountability to create gorgeous content material for the pupils, averting fabric that is too easy, too dull, or too challenging.

2. More exercise in micro-skills must be developed via the teacher. More micro-skills exercise must be supplied through the teacher. The instructor have to proportionately incorporate listening features, macro and micro-skills in the check or content.

3. During team discussions, the instructor must be greater conscious of the students' issues. In order to keep away from dominating and passive pupils in a group, the instructor establish sturdy rules. The instructor should additionally supply a strong foundation for the conversation.

4. The subsequent researcher can undertake in-depth learn about and focus on students' engagement in crew discussions or on a particular factor of listening, either macro- or micro-skills.

\section{REFERENCES}

[1] Osada, N. (2004). Listening comprehension research: A brief review of the last thirty years. 2004 TALK Japan. [in English].

[2] Chang, A.-S. C., \& Read, J. (2006). The effects of listening support on the listening performance of EFL learners. TESOL Quarterly, 40(2). https://doi.org/10.2307/40264527. [in English].

[3] Holden, W. R., III (2008). Extensive listening: A new approach to an old problem. Bulletin of Faculty of Humanities, University of Toyama [in English].

[4] Krashen, S. (1985). The input hypothesis: Issues and implications. Laredo [in English].

[5] Cooper, J., \& Mueck, R. (1990). Student involvement in learning: Cooperative learning and college instruction. Journal on Excellence in College Teaching, 1(1). [in English].

[6] Gliddon, J., \& Kurfiss, J. G. (1990). Small-group discussion in Philosophy 101. College Teaching, 38(1). [in English].

[7] Sharan, Y., \& Sharan, S. (1994). Group investigation in the cooperative classroom. In S. Sharan (Ed.), Handbook of cooperative learning methods Greenwood Press [in English].

[8] Smith, K. A. (1996). Cooperative learning: Making "groupwork" work. In T. E. Southerland \& C.C. Bonwell (Eds.), Using active learning in college classes: A range of options for faculty. Jossey-Bass [in English].

[9] Faust, J. L., \& Paulson, D. R. (1998). Active learning in the college classroom. Journal of Excellence in College Teaching, 9(2). [ in English].

[10] Gebhard, J. (2000) Teaching English as a Foreign Language. Michigan: Michigan University Press. [in English]. 
[11] Brown, D. H. (2007) Teaching by Principles. An Interactive Approach to Language Pedagogy (Third Edition). White Palins: Addison Wesley Longman. [in English].

[12] Immerwahr, J. (2011) Enhancing Class Discussion. April 23, 2014. Retrieved from http://teachphilosophy101.org/Default.aspx?tabid=101 [in English].

[13] Zander, A. (1979) The Discussion Period in a College Classroom. Memo to the Faculty, 62. Ann Arbor, MI: Center for Research on Learning and Teaching. [in English].

[14] Reineke, M. J. (2014) In-Class Discussion. April 23, 2014. Retrieved from www.uni.edu/reineke/guidelin.htm [in English].

[15] Antonjjansen. (2012) Micro and Macro Listening Skills (Introduction). Nov $11^{\text {th }}, 2013$. Retrieved from http://forums.antonjjansen.net/esl_forum/thread-5.html [in English].

\section{Абилтаева А. Н. \\ СТУДЕНТТЕРДІ ШЕТ ТІЛІНДЕ ТЫНДАУ ДАҒДЫЛАРЫН ДАМЫТУДАҒЫ ТОПТЫҚ ПІКІРТАЛАС}

Аңдатпа. Бұл зерттеудің мақсаты студенттердің топтық талқылауда тыңдауды үйренудегі мәселелерін қарастыру, сонымен қатар тыңдаудың қай аспектісі басқасына қарағанда жақсы жұмыс істейтінін білу болды. Ақпарат сауалнама, алдын-ала тестілеу және одан кейінгі тестілеу арқылы жиналды. Тестілеуге дейінгі және кейінгі мәліметтер түсіндіру, орташа мәнді есептеу және оқушылардың макро - және микро-дағдыларға жауаптарын салыстыру арқылы талданды. Нәтижелер студенттердің бес негізгі проблемасы бар екенін көрсетті: талқылау кезінде басқа нәрсе туралы сөйлесу, салымның болмауы, үстем дос, топтық жолдас және пікірталас жетекшісі болуға дайын болу. Балалар тыңдау дағдыларына жеткен кезде микро дағдыларға қарағанда макро дағдылармен жақсы жұмыс жасады. Соңында, "жоғарыдан төмен" процесте схемалардың болуына байланысты пікірталастың жетілмеген жағдайына байланысты талқылаудағы проблемалар туындауы мүмкін және макро дағдылар жақсы жұмыс істей алады.

Кілт сөздер: Топтық талқылау, тыңдау, макро және микро-дағдылар, түсіну, тыңдау дағдылары, топтық жұмыс, белсенді оқыту, пікірталас іс-шаралары, есеп беру.

\section{Абилтаева А.Н. ГРУППОВАЯ ДИСКУССИЯ В РАЗВИТИИ НАВЫКОВ АУДИРОВАНИЯ СТУДЕНТОВ НА ИНОСТРАННОМ ЯЗЫКЕ}

Аннотация. Цели этого исследования состояли в том, чтобы рассмотреть проблемы, с которыми сталкивались студенты при обучении аудированию в групповой дискуссии, а также выяснить, какой аспект слушания работает лучше, чем другой. Информация была собрана с помощью вопросника, предварительного тестирования и последующего тестирования. Данные до и после тестирования были проанализированы путем интерпретации, вычисления среднего значения и сравнения ответов учащихся на макро- и микро-навыки. Результаты показали, что у студентов было пять ключевых проблем: разговор о чем-то другом во время обсуждения, отсутствие вклада, доминирующий друг, товарищ по группе и готовность быть лидером дискуссии. Дети лучше справлялись с макро-навыками, чем с микро-навыками, когда дело доходило до навыков слушания. Наконец, из-за наличия схем в процессе "сверху вниз" проблемы в обсуждении могут возникать из-за несовершенного состояния дебатов, и макро-навыки могут работать лучше.

Ключевые слова: Групповое обсуждение, слушание, макро и микро-навыки, понимание, навыки слушания, групповая работа, активное обучение, дискуссионные мероприятия, отчет. 